\title{
INTERSECTORAL LINKAGES AND THEIR CONTRIBUTION TO ECONOMIC GROWTH IN THE REPUBLIC OF SERBIA
}

\author{
UDC 330.35(497.11)
}

\author{
Jelena Stanojević ${ }^{\text {, Bojan Krstić }}{ }^{2}$ \\ ${ }^{1}$ University of Niš, Faculty of Sciences and Mathematics, Serbia \\ ${ }^{2}$ University of Niš, Faculty of Economics, Serbia
}

\begin{abstract}
The high level of interconnection between economic sectors, namely agriculture, manufacturing and the service sector, imposes the need to understand intersectoral structural changes and transfer of resources between sectors in order to perceive their contribution to economic development. Based on the rich information base compiled by data from various national and international statistic sources, intersectoral structural changes in the Republic of Serbia as one of the transition economies are analysed from different aspects. The paper deals primarily with the share of economic sectors in the gross domestic product. Further, it points to the participation of economic sectors in overall employment, but also in international trade. The research goal is to analyze the structural changes in the Serbian economy, identify the direction of resource transfer between sectors, as well as their contribution to the economic development measured by different indicators.
\end{abstract}

Key words: intersectoral linkages, structural changes, economic growth, Republic of Serbia.

JEL Classification: E01, O11, O40

Received December 14, 2018 / Revised April 29, 2019 / Accepted May 03, 2019

Corresponding author: Jelena Stanojević

University of Niš, Faculty of Sciences and Mathematics, Višegradska 33, 18000 Niš, Serbia

E-mail: jelenastanojevic83@yahoo.com 


\section{INTRODUCTION}

The economic growth of developed countries is characterized by the reallocation of resources from agriculture to non-agricultural activities, accompanied by further shifts from manufacturing to the service sector.

In general, several important phases of these changes can be distinguished (Adelman, 1999, pp. 103-134). In the first stage of development, a large part of the active workforce is related to agriculture. Along with the progress, there is a movement of the labour force from agriculture to the manufacturing and service sector. The service sector also advances simultaneously with manufacturing due to its multiple interconnection, primarily in the domain of transport, distribution and finance. Therefore, both sectors show an increase in relative importance in relation to agriculture. However, over a certain period of economic development, the participation of manufacturing in the total employment is stabilized, while on the other hand the service sector continues to expand at the expense of the agricultural sector. In the final stage of development, the economy reaches its peak. During this phase, the service sector continues to progress, but now at the expense of manufacturing whose relative significance is decreasing. If the service sector continues to grow and there is no increase in the total active labour force, this increase is possible only with a significant reduction of employment in manufacturing as well (Kenneth et al., 1992, pp. 2).

The economic justification for such long-term movement between sectors can be found both on the supply and demand side. Firstly, the relative importance of agriculture should be considered. On the supply side, a large increase in productivity leading to an increase in agricultural production is a result of a mechanization development, improved transport, greater use of fertilizers and pesticides, as well as the overall advancement of scientific knowledge and techniques of agricultural management. However, productivity growth is not accompanied by a steady increase in demand for agricultural products (Johnston, 1990, pp. 1109-1123). The growth in income per capita usually goes hand in hand with a decrease in the income elasticity for demand of food, which ends up with the creation of surplus products. As a result, there is a decline in agricultural product prices, profitability and farmers' earnings, and the movement of workers from agriculture due to lack of work or inadequate salaries (Kenneth et al., 1992, pp. 5).

On the other hand, an increase in the relative importance of the service sector can be also explained by factors on the supply and demand side (Hayami and Godo, 2005, p. 32). The original explanations focused on the demand side. High income elasticity of demand for services at a high level of income per capita indicates the prosperity of the economy where more revenue is allocated and spent on services. However, only a small part of the employment growth in the service sector can be justified by the demand for services. Interestingly, the rise in some of the services is closely linked to the rising demand for both agricultural and manufacturing products (e.g. travel, entertainment, etc.) (Kenneth et al., 1992, pp. 5).

Certain movements within the economy of the Republic of Serbia (further: Serbia or RS) as one of the transition economies also indicate a change in sectors' relative importance. The structure of the Serbian economy has been constantly evolving in response to ever-changing domestic and international conditions. Serbia has had a period of rapid structural changes with a changing external environment, but also an 
internal environment with regards to the changed demographics. While the external environment has special significance in the secondary sector, the main factors of the structural changes in the agricultural sector are internal (although often with an international dimension).

Unlike the agricultural sector, the service sector in Serbia has been unstoppable in the previous period. Also, manufacturing shifted to the production of knowledge-based products in order to put emphasis on design and other value-added components. Computerization and information technology have replaced thousands of office workers who have sought work in other service activities.

In economic theory is widely accepted the existence of interrelation between economic growth and structural changes, whether measured by the employment share of economic sectors or through their participation in the realized domestic or international value (Dietrich, 2009). Therefore, the paper primarily focuses on intersectoral structural changes. After examining the theoretical framework of the concept of structural changes, intersectoral structural changes in the Serbian economy are elaborated from the aspect of sectors' share in gross domestic product, employment and international trade.

\section{THEORETICAL FRAMEWORK:}

\section{The Conceptual Basis of Structural Changes in the EConomy}

Structural changes, their theoretical perception and analysis of the factors that have caused them, have attracted the attention of prominent economists in the past (Krstić et al., 2015, pp. 31-44). However, despite the rich research base in this field, there are certain doubts in the literature regarding interpretation of the concept of structural changes. Namely, the term "structural change" has not always been used in this form bearing in mind that economists dealt with its analysis, but using a different terminology (Quatraro, 2012, pp. 37-38).

Structural changes, analyzed in that period as structural transformations, were one of the main topics in the classical economy. Neoclassical economists have not considered structural changes as an important factor of economic development, but only as the automatic result of market development. While neoclassical economists have not attached great importance to this problem, classical economists have considered structural changes from the perspective of moving labour from agriculture as a traditional activity, to manufacturing and services as modern activities (Memedovic \& Lapadre, 2010, p. 4).

One of the most prominent representatives of the classical economy, Adam Smith, emphasized in his work "Wealth of Nations" (1776) that agriculture is mainly specializing in poorer countries, where the nature of tasks being performed determines the division of labour and thus limits production efficiency. On the other hand, richer countries specialize in manufacturing, bearing in mind that manufacturing activities provide the ability to perform a variety of tasks and thereby increase productivity. At the same time, Smith under structural changes implied carrying out production activities within organizations, and not just a sectoral composition of the economic system (Quatraro, 2012, p. 37). 
Apart from Adam Smith, also Simon Kuznec (1930), Artur Burns (1934) and Alan Fisher (1939) greatly contributed to the study of structural changes. Important empirical evidence can be found in their works about the rise and fall of certain economic sectors, but above all the manufacturing sector. They also provided an explanation of factors that have led to changes in industrial leadership in different countries. Bearing that in mind, Kuznec considered structural changes to be one of the important factors of development, although it meant only sectoral changes in employment and production. From this perspective, the economic development of countries and regions is strictly defined by performance of the leading sectors (Krstić et al., 2015, pp. 31-44).

Classical economists, primarily Kuznec, Burns and Fischer, have provided an interpretation of structural changes starting from the three-sector model of the economy. In doing so, the economy can be divided into three major economic aggregates: the primary sector that includes agriculture, fishery and forestry; a secondary sector that includes the production of capital and consumption goods through the combination of capital, labour and intermediate goods; and a tertiary sector that involves the provision of various services. The replacement of the contribution of three main sectors to the overall development of the economy represents the backbone of the classical model (Krstić et al., 2015, pp. 31-44).

Kuznec, as one of the initiators of the empirical analysis of structural changes, has laid the foundations of the so-called theory of slowdown in development. The initial assumption of this theory is the uneven growth rates, as well as the interweaving of cross-sectoral and international dimensions. Starting from this, the achieved level of development of each country depends to a great extent and is determined by the dominant sector of the economy. Therefore, a contribution of Kuznets and his theory of slowdown in development is pointing out important structural transformations (changes) of the economy as one of the crucial features of modern economic growth. At the same time, fundamental assumptions of structural changes are a change in the focus of the economy from agriculture to manufacturing and from manufacturing to services, as well as changes in the scale of production units and a shift towards other forms of organization of economic entities other than their own enterprises (Quatraro, 2012, p. 42).

However, other economists who offered some interpretations of structural changes were also distinguished. For instance, according to Robinson and Sirkin, structural changes are a set of changes in production and demand, trade, and the use of factors reflected in the income per capita increase (Ark, 1995, p. 1). Further, Maklup (1963) puts emphasis on the distribution of factors of production between the economic sectors, territories, various products, occupations, etc. and under structural changes he first of all takes into account different arrangements of production activities in the economy (Quatraro, 2012, p. 37).

"Although the concept of structural changes can be defined in different ways, it most often refers to long-term and lasting changes in the sectoral composition of the state or region during the economic development process. More specifically, structural changes are associated with the modification of a relative importance of different sectors over time, measured by their participation in production and employment" (Krstić et al., 2015, pp. 31-44). 
The concept of structural changes is difficult to be uniquely defined due to the complexity of the phenomenon. Also, there is a low possibility of finding a universal method of their measurement. However, it is generally accepted that structural changes can be measured by reallocating capital and labour between sectors and regions, depending on the level being analyzed. Changes in the sector, in markets of goods and services, and in the nature of production processes should also be taken into account (Raiser et al., 2003).

Therefore, structural changes can be identified and monitored having in mind different levels. They occur, above all, in the conditions when companies respond to changes in relative input and output prices, but also to challenges arising from the emergence of new technology and knowledge. However, in the case of the same or similar effects of structural changes to all economic actors within the sector, it is considered that they occur at a sectoral level. Structural changes can also be manifested between sectors as well as within them. Nevertheless, the most intense are those that occur at the macroeconomic level, causing changes of varying intensity in all sectors. Consequently, three levels of structural change can be distinguished (Downes \& Stoeckel, 2006, p. 12):

1. At the enterprise level - implementation of modern technology, new management methods, modern production practices, response to changes in relative labour costs, capital and other factors of production;

2. At the sector level - certain structures of companies are favourable under the pressure of competition, but changes occur in the operating environment along with the change in input prices;

3. Between sectors - changes in domestic demand, but also in global terms lead to conditional changes in consumption patterns (usually as a result of demographic changes, the application of modern technology, etc.), the change in the comparative advantage of the economic sectors determines the outcome of the market game.

The key to successful adaptation to structural change is adaptability, flexibility and competitiveness (which leads to innovation and adaptation). These characteristics are associated with a high level of productivity, rising revenue and a low inflation rate in the country. For this reason, macroeconomic policy makers seek to maintain a macroeconomic environment with low interest and unemployment rates. A good macroeconomic and microeconomic policy should be strongly mutually complementary (Downes \& Stoeckel, 2006, p. 5).

\section{RESEARC RESULTS AND DISCUSSION}

\subsection{The share of economic sectors in the gross domestic product of the Republic of Serbia}

Gross domestic product (GDP) in the last fifty years has been the most often used indicator of economic progress of a country and welfare of its population. This indicator shows how efficiently the economy functions by compressing the total value of state economic activities in only one number (Mankiw, 2002, p. 53). 
"GDP represents the market value of all finished goods and services produced within a country over a given period of time" (Mankiw, 2001, p. 208). It can be calculated by summarizing the "value of personal consumption expenditure (consumption of households for goods and services), government expenditure (public expenditures for the provision of goods and services for the future) and net exports (difference in value between government exports and imports)" (Mankiw, 2001, p. 208).

According to the degree of development, measured by GDP per capita, national economies can be classified into three groups: factor-driven, efficiency-driven, and innovation-driven (Table 1).

Table 1 Different levels of the economic development

\begin{tabular}{lccccc}
\hline & $\begin{array}{r}\text { Level 1: } \\
\text { Factor } \\
\text { driven }\end{array}$ & $\begin{array}{c}\text { Transition } \\
\text { from level 1 } \\
\text { to level 2 }\end{array}$ & $\begin{array}{c}\text { Level 2: } \\
\text { Efficiency } \\
\text { driven }\end{array}$ & $\begin{array}{c}\text { Transition } \\
\text { from level 2 } \\
\text { to level 3 }\end{array}$ & $\begin{array}{c}\text { Level 3: } \\
\text { Innovation } \\
\text { driven }\end{array}$ \\
\hline GDP per capita & $<2000$ & $2000-2999$ & $3000-8999$ & $9000-17000$ & $>17000$ \\
Subindex "Basic factors" & $60 \%$ & $40-60 \%$ & $40 \%$ & $20-40 \%$ & $20 \%$ \\
Subindex "Efficiency factors" & $35 \%$ & $35-50 \%$ & $50 \%$ & $50 \%$ & $50 \%$ \\
$\begin{array}{l}\text { Subindex "Innovation and } \\
\text { sophistication factors" }\end{array}$ & $5 \%$ & $5-10 \%$ & $10 \%$ & $10-30 \%$ & $30 \%$ \\
\hline
\end{tabular}

Source: WEF. (2016-2017). Global Competitiveness Report. Geneva: World Economic Forum, p. 38

The economy is driven by factors of production in the first stage of economic development. Countries at this level of development compete with the engagement of the basic factors of production, primarily human and natural resources. Companies base their competitiveness on low prices and sale of mainly basic products, achieving low productivity and low wages.

As the economy becomes more competitive, it increases productivity and earnings of workers. National economies are moving towards a stage of development that is efficiency driven. At this stage, the production process and product quality should be improved since earnings of workers grow, but prices of products cannot be increased. Competitiveness at this level is focused on higher education, efficient financial market and market of goods and services, etc.

Innovation driven economy as the highest level of a country development encourages companies to produce innovative and distinguished products that will contribute to the overall competitiveness. At this stage of development, in addition to the previously mentioned factors of development, the crucial roles in the economy development belong to intangible forms of capital, such as research and development, science, education, innovation, competencies, etc. Hovewer, the outcome of these fields largely depends on sufficient level of investment, proving that the financial capital is still of high importance at this level of economy development (Frane, 2014, pp. 1-2). 
Table 2 shows data for gross domestic product of Serbia in RSD, USD, and EUR in the period 2000-2015.

Based on Table 2, GDP per capita of Serbia in 2015 amounted to 5,235 USD representing half of the value in Efficiency driven stage (3000-8999 USD). Accordingly, Serbia has to increase GDP in order to qualify for the transition to a higher stage.

Table 2 GDP of the Republic of Serbia in RSD, EUR, USD, in the period 2000-2015

\begin{tabular}{rrrrrr}
\hline & Total mil. RSD & \multicolumn{2}{c}{ Total mil. EUR Per capita, EUR } & \multicolumn{2}{c}{ Total mil. USD Per capita, USD } \\
\hline 2000 & $1,989,783.5$ & $25,717.0$ & $3,421.5$ & $23,593.5$ & $3,139.0$ \\
\hline 2001 & $2,089,127.7$ & $12,928.5$ & $1,723.0$ & $11,581.1$ & $1,543.4$ \\
2002 & $2,237,785.6$ & $16,213.8$ & $2,161.8$ & $15,277.3$ & $2,037.0$ \\
\hline 2003 & $2,336,593.1$ & $17,486.8$ & $2,337.6$ & $19,755.1$ & $2,640.9$ \\
2004 & $2,547,973.3$ & $19,128.0$ & $2,563.0$ & $23,776.4$ & $3,185.8$ \\
\hline 2005 & $2,689,141.9$ & $20,407.6$ & $2,742.7$ & $25,361.2$ & $3,408.4$ \\
2006 & $2,821,026.8$ & $23,610.0$ & $3,185.6$ & $29,603.7$ & $3,994.3$ \\
2007 & $2,987,150.3$ & $28,784.6$ & $3,899.5$ & $39,385.4$ & $5,335.6$ \\
2008 & $3,147,461.2$ & $33,417.9$ & $4,546.5$ & $48,856.6$ & $6,647.0$ \\
\hline 2009 & $3,049,387.2$ & $29,967.0$ & $4,093.4$ & $41,658.7$ & $5,690.5$ \\
2010 & $3,067,210.2$ & $29,766.3$ & $4,082.0$ & $39,370.4$ & $5,400.0$ \\
\hline 2011 & $3,110,196.1$ & $33,423.8$ & $4,619.0$ & $46,463.7$ & $6,421.0$ \\
2012 & $3,078,619.2$ & $31,683.1$ & $4,400.0$ & $40,675.9$ & $5,648.0$ \\
\hline 2013 & $3,157,793.1$ & $34,262.9$ & $4,781.0$ & $45,512.1$ & $6,351.0$ \\
\hline 2014 & $3,908,469.6$ & $33,186.0$ & $4,672.0$ & $44,143.1$ & $6,190.0$ \\
\hline 2015 & $4,043,467.8$ & $33,491.0$ & $4,720.0$ & $37,145.7$ & $5,235.0$ \\
\hline
\end{tabular}

Source: Statistical office of the Republic of Serbia (2005-2016). Statistical Yearbook.

In Table 3, the gross value added and gross domestic product of Serbia from 2000 to 2014 are given. Based on the provided information, all occupations in the analysed period achieved a rise in absolute values in dinars. However, the highest increase is recorded in wholesale and retail sale trade, information and communication, and financial activities. The total gross value added of Serbia in 2014 compared to 2000 increased by $37 \%$, while gross domestic product has been increased by $56 \%$.

Table 4 shows the gross domestic product of Serbia, overall and per economic sectors, in absolute and relative values in the period 2000-2014. The share of primary sector in gross value added in the analyzed period is around $10 \%$, the share of secondary sector is around $30 \%$, and the share of tertiary sector is around $60 \%$ in gross value added. 
Table 3 Gross value added per occupation and gross domestic product of Serbia, in the period 2000-2014, constant price 2010

\begin{tabular}{|c|c|c|c|c|c|c|c|c|}
\hline & 2000 & 2001 & 2002 & 2003 & 2004 & 2005 & 2006 & 2007 \\
\hline Agriculture, forestry and fishing & 223,897 & 262,560 & 24,460 & 227,688 & 271,093 & 257,961 & 257,784 & 237,455 \\
\hline Mining & 24,947 & 19,126 & 30,479 & 34,597 & 35,570 & 36,075 & 39,242 & 36,671 \\
\hline Manufacturing & 428,713 & 387,339 & 364,526 & 368,014 & 381,653 & 381,491 & 388,732 & 425,533 \\
\hline Electricity, gas and steam supply & 64,114 & 64,895 & 63,808 & 72,909 & 77,755 & 78,702 & 82,495 & 86,613 \\
\hline $\begin{array}{l}\text { Water supply and waste water } \\
\text { management }\end{array}$ & 31,771 & 28,423 & 26,601 & 29,592 & 29,878 & 32,163 & 32,372 & 33,275 \\
\hline Construction & 82,317 & 73,650 & 94,209 & 116,470 & 131,611 & 130,504 & 150,964 & 151,241 \\
\hline $\begin{array}{l}\text { Wholesale and retail trade, repair of } \\
\text { motor vehicles }\end{array}$ & 118,037 & 109,030 & 132,120 & 153,236 & 183,923 & 251,227 & 275,581 & 315,113 \\
\hline Traffic and storage & 79,191 & 84,031 & 86,908 & 92,967 & 101,493 & 106,350 & 123,313 & 137,448 \\
\hline Accomodation and food services & 34,993 & 30,267 & 28,607 & 32,415 & 32,957 & 36,178 & 40,991 & 38,787 \\
\hline Information and communication & 54,840 & 55,318 & 64,871 & 74,040 & 75,572 & 85,530 & 97,398 & 118,189 \\
\hline Financial and insurance activities & 39,007 & 31,950 & 35,104 & 37,547 & 43,375 & 51,885 & 67,912 & 82,070 \\
\hline Real estate & 244,580 & 247,891 & 252,198 & 251,607 & 253,149 & 268,004 & 269,579 & 271,238 \\
\hline $\begin{array}{l}\text { Professional, scientific, innovation } \\
\text { and technical activities }\end{array}$ & 89,662 & 61,312 & 58,976 & 54,666 & 69,689 & 72,644 & 82,097 & 95,664 \\
\hline $\begin{array}{l}\text { Administrative and support service } \\
\text { activities }\end{array}$ & 30,888 & 23,515 & 21,574 & 24,625 & 43 & 31,715 & 32,265 & 2 \\
\hline $\begin{array}{l}\text { Public administration and } \\
\text { mandatory social security }\end{array}$ & 93,211 & 93,637 & 96,120 & 104,565 & 111,350 & 111,027 & 105,566 & 105,977 \\
\hline Education & 81,028 & 83,212 & 90,742 & 100,238 & 100,752 & 93,896 & 8,925 & 97,152 \\
\hline Health and social protection & 164,235 & 165,002 & 178,192 & 164,812 & 169,413 & 175,978 & 156,892 & 158,930 \\
\hline Art, entertainment and recreation & 23,318 & 18,806 & 24,231 & 30,803 & 36,064 & 32,362 & 31,324 & 29,915 \\
\hline Other service activities & 36,245 & 32,520 & 38,565 & 38,274 & 46,854 & 48,444 & 53,431 & 48,025 \\
\hline Household activities as an employer & I & I & 1,166 & 1,362 & 1,491 & 2,151 & 2,185 & 3,049 \\
\hline Gross value added (GVA) & $1,912,735$ & $1,876,382$ & $1,923,646$ & $2,000,511$ & $2,171,702$ & $2,276,854$ & $2,379,219$ & $2,506,273$ \\
\hline ducts & 147,686 & 261,878 & 354,700 & 371,379 & 418,854 & 450,830 & 480,273 & 515,771 \\
\hline Subsidies on products & 26,730 & 30,953 & 30,271 & 28,764 & 34,246 & 33,173 & 34,284 & 32,793 \\
\hline \multirow[t]{2}{*}{ Gross domestic products (GDP) } & $1,989,784$ & $2,089,128$ & $2,237,786$ & $2,336,593$ & $2,547,973$ & $2,689,142$ & $2,821,027$ & $2,987,150$ \\
\hline & & 2008 & 2009 & 2010 & 2011 & 2012 & 2013 & $\overline{2014}$ \\
\hline Agriculture, forestry and fishing & & 258,115 & 245,814 & 261,510 & 263,993 & 218,348 & 264,004 & 269,181 \\
\hline Mining & & 37,896 & 33,855 & 39,964 & 46,237 & 49,087 & 49,712 & 38,116 \\
\hline Manufacturing & & 439,706 & 419,839 & 418,466 & 426,237 & 458,870 & 484,882 & 474,874 \\
\hline Electricity, gas and steam supply & & 85,958 & 91,421 & 87,245 & 90,458 & 88,180 & 99,638 & 70,955 \\
\hline Water supply and waste water managem & & 31,046 & 31,149 & 35,131 & 36,638 & 36,750 & 36,444 & 36,888 \\
\hline Construction & & 171,052 & 149,069 & 145,484 & 154,069 & 138,927 & 133,558 & 131,578 \\
\hline Wholesale and retail trade, repair of mot & r vehicles & 327,182 & 298,331 & 289,462 & 290,567 & 292,955 & 297,416 & 299,518 \\
\hline Traffic and storage & & 134,762 & 128,540 & 137,687 & 137,323 & 126,694 & 136,261 & 140,031 \\
\hline Accomodation and food services & & 35,580 & 35,365 & 34,540 & 31,628 & 35,458 & 32,588 & 31,819 \\
\hline Information and communication & & 129,482 & 125,571 & 129,593 & 132,926 & 136,597 & 136,420 & 131,160 \\
\hline Financial and insurance activities & & 97,543 & 100,035 & 101,894 & 100,304 & 92,250 & 83,509 & 81,150 \\
\hline Real estate & & 282,176 & 283,885 & 284,579 & 285,981 & 288,791 & 291,778 & 287,948 \\
\hline $\begin{array}{l}\text { Professional, scientific, innovation and te } \\
\text { activities }\end{array}$ & anical & 102,704 & 91,859 & 89,343 & 92,882 & 95,942 & 94,535 & 95,733 \\
\hline Administrative and support service activi & & 38,973 & 41,775 & 44,350 & 43,507 & 45,773 & 43,814 & 43,803 \\
\hline Public administration and mandatory soc & al security & 106,881 & 111,454 & 111,198 & 112,532 & 117,736 & 120,492 & 118,847 \\
\hline Education & & 102,826 & 104,851 & 105,363 & 106,982 & 108,776 & 110,275 & 111,204 \\
\hline Health and social protection & & 164,889 & 166,001 & 164,644 & 169,502 & 169,618 & 169,977 & 171,120 \\
\hline Art, entertainment and recreation & & 30,527 & 29,824 & 30,113 & 27,906 & 30,130 & 29,530 & 29,897 \\
\hline Other service activities & & 48,722 & 46,103 & 44,108 & 42,578 & 41,058 & 39,195 & 40,243 \\
\hline Household activities as an employer & & 3,023 & 2,670 & 2,692 & 2,532 & 2,517 & 2,531 & 2,724 \\
\hline Gross value added (GVA) & & $2,627,770$ & $2,537,137$ & $2,557,364$ & $2,594,783$ & $2,574,024$ & $2,658,472$ & $2,604,582$ \\
\hline Taxes on products & & 554,878 & 544,112 & 543,004 & 549,024 & 531,759 & 530,515 & 526,543 \\
\hline Subsidies & & 34,235 & 31,869 & 33,158 & 33,611 & 27,497 & 32,727 & 32,790 \\
\hline Gross domestic products (GDP) & & $3,147,461$ & $3,049,387$ & $3,067,210$ & $3,110,196$ & $3,078,619$ & $3,157,793$ & $3,099,964$ \\
\hline
\end{tabular}

Source: Statistical office of the Republic of Serbia (2005-2016). Statistical Yearbook. 
Table 4 Gross domestic product per economic sectors in Serbia, in the period 2000-2014 (constant price 2010, mil. RSD)

\begin{tabular}{|c|c|c|c|c|c|c|c|}
\hline \multirow[b]{2}{*}{ Year } & \multirow{2}{*}{$\begin{array}{c}\text { Gross } \\
\text { domestic } \\
\text { product }\end{array}$} & \multicolumn{2}{|c|}{ Agriculture } & \multicolumn{2}{|c|}{ Manufacturing } & \multicolumn{2}{|c|}{ Service sector } \\
\hline & & $\begin{array}{l}\text { Mil. } \\
\text { RSD }\end{array}$ & $\begin{array}{c}\% \text { of total } \\
\text { GDP }\end{array}$ & $\begin{array}{l}\text { Mil. } \\
\text { RSD }\end{array}$ & $\begin{array}{c}\% \text { of total } \\
\text { GDP }\end{array}$ & $\begin{array}{l}\text { Mil. } \\
\text { RSD }\end{array}$ & $\begin{array}{c}\% \text { of total } \\
\text { GDP }\end{array}$ \\
\hline 2000 & $1,944,993.2$ & $223,896.7$ & $12 \%$ & $631,862.1$ & $32 \%$ & $1,089,234.4$ & $56 \%$ \\
\hline 2001 & $1,872,481.1$ & $262,559.7$ & $14 \%$ & $573,432.7$ & $31 \%$ & $1,036,488.7$ & $55 \%$ \\
\hline 2002 & $1,933,596.9$ & $244,600.1$ & $13 \%$ & $579,622.9$ & $30 \%$ & $1,109,373.9$ & $57 \%$ \\
\hline 2003 & $2,010,427.1$ & $227,687.6$ & $11 \%$ & $621,582.8$ & $31 \%$ & $1,161,156.7$ & $58 \%$ \\
\hline 2004 & $2,176,180.5$ & $271,092.8$ & $12 \%$ & $656,466.0$ & $30 \%$ & $1,248,621.7$ & $57 \%$ \\
\hline 2005 & $2,284,289.5$ & $257,961.1$ & $11 \%$ & $658,934.8$ & $29 \%$ & $1,367,393.6$ & $60 \%$ \\
\hline 2006 & $2,379,372.7$ & $257,784.0$ & $11 \%$ & $693,804.0$ & $29 \%$ & $1,427,784.7$ & $60 \%$ \\
\hline 2007 & $2,506,045.2$ & $237,455.2$ & $9 \%$ & $733,332.8$ & $29 \%$ & $1,535,257.2$ & $61 \%$ \\
\hline 2008 & $2,629,041.7$ & $258,115.2$ & $10 \%$ & $765,657.3$ & $29 \%$ & $1,605,269.2$ & $61 \%$ \\
\hline 2009 & $2,537,409.2$ & $245,813.6$ & $10 \%$ & $725,332.8$ & $29 \%$ & $1,566,262.8$ & $62 \%$ \\
\hline 2010 & $2,557,364.2$ & $261,510.4$ & $10 \%$ & $726,288.7$ & $28 \%$ & $1,569,565.1$ & $61 \%$ \\
\hline 2011 & $2,594,782.3$ & $263,993.0$ & $10 \%$ & $753,640.3$ & $29 \%$ & $1,577,149.0$ & $61 \%$ \\
\hline 2012 & $2,574,454.6$ & $218,348.1$ & $8 \%$ & $771,813.4$ & $30 \%$ & $1,584,293.1$ & $62 \%$ \\
\hline 2013 & $2,656,558.9$ & $264,003.6$ & $10 \%$ & $804,233.8$ & $30 \%$ & $1,588,321.5$ & $60 \%$ \\
\hline 2014 & $2,604,582.4$ & $269,181.0$ & $10 \%$ & $752,411.0$ & $29 \%$ & $1,585,197.0$ & $61 \%$ \\
\hline
\end{tabular}

Source: Statistical office of the Republic of Serbia (2005-2016). Statistical Yearbook.

Based on the previous table, the tertiary sector has increased its relative importance over years measured by its share in GDP, from 56\% in 2000 to $61-62 \%$ at the end of analyzed period. The primary sector achieved the biggest share in GDP in $2001(14 \%)$ and the smallest in $2012(8 \%)$, while secondary sector showed very small fluctuations in the share of GDP from $32 \%$ in 2000 to $28 \%$ in 2010.

\subsection{The share of economic sectors in the overall employment of the Republic of Serbia}

In the last two centuries, drastic changes have been occurring in employment and productivity between the economic sectors. History has shown that economies changed from predominantly agricultural, via manufacturing, to service-focused economies.

The economic development of industrialized countries has led to the transformation of society. In countries striving for industrialization, agriculture has served as a source of resources that can be invested in economic development activities. Among other things, gradually there was a migration of the agricultural population to manufacturing and service sector, and then at a higher level of development from manufacturing into the service sector.

Table 5 shows the movement of overall employment in Serbia in the period from 2002 to 2014, as well as in all economic activities (agriculture, manufacturing, and service activities).

The number of employees in Serbia is in constant decline, from 1.6 million in 2002 to 1.3 million in 2014. Observed by sectors in the analyzed period, the employees in agriculture registered a decline in the share of total employment in Serbia from $4.82 \%$ to $2.36 \%$. The relative share of manufacturing in Serbian total employment also drops, from $44.13 \%$ in 2002 to $32.23 \%$ in 2014 . Unlike the primary and secondary sectors, 
the participation of the tertiary sector in the overall employment of Serbia increased in the observed period from $52.29 \%$ to $65.41 \%$, thus representing a dominant share.

Table 5 Employees per sector in Serbia, in the period 2002-2014

\begin{tabular}{cccccccc}
\hline \multirow{2}{*}{ Year } & Number of & \multicolumn{2}{c}{ Agriculture } & \multicolumn{2}{c}{ Manufacturing } & \multicolumn{2}{c}{ Service sector } \\
\cline { 3 - 8 } & employees & Absolute & Relative & Absolute & Relative & Absolute & Relative \\
\hline 2002 & $1,676,835$ & 80,888 & $4.82 \%$ & 739,932 & $44.13 \%$ & 856,044 & $51.05 \%$ \\
2003 & $1,611,632$ & 74,445 & $4.62 \%$ & 694,420 & $43.09 \%$ & 842,771 & $52.29 \%$ \\
2004 & $1,580,140$ & 70,073 & $4.43 \%$ & 650,518 & $41.17 \%$ & 859,555 & $54.40 \%$ \\
2005 & $1,546,471$ & 65,058 & $4.21 \%$ & 624,120 & $40.36 \%$ & 857,295 & $55.44 \%$ \\
2006 & $1,471,750$ & 59,395 & $4.04 \%$ & 578,809 & $39.33 \%$ & 833,548 & $56.64 \%$ \\
2007 & $1,432,851$ & 55,145 & $3.85 \%$ & 543,154 & $37.91 \%$ & 834,555 & $58.24 \%$ \\
2008 & $1,428,457$ & 49,528 & $3.47 \%$ & 522,026 & $36.54 \%$ & 856,905 & $59.99 \%$ \\
2009 & $1,396,792$ & 46,129 & $3.30 \%$ & 486,468 & $34.83 \%$ & 864,198 & $61.87 \%$ \\
2010 & $1,354,637$ & 37,392 & $2.76 \%$ & 459,006 & $33.88 \%$ & 858,242 & $63.36 \%$ \\
2011 & $1,342,892$ & 34,815 & $2.59 \%$ & 449,963 & $33.51 \%$ & 858,113 & $63.90 \%$ \\
2012 & $1,341,114$ & 33,002 & $2.46 \%$ & 443,726 & $33.09 \%$ & 864,385 & $64.45 \%$ \\
2013 & $1,338,082$ & 33,715 & $2.44 \%$ & 438,990 & $32.81 \%$ & 866,378 & $64.75 \%$ \\
2014 & $1,323,831$ & 31,288 & $2.36 \%$ & 426,670 & $32.23 \%$ & 865,871 & $65.41 \%$ \\
\hline
\end{tabular}

Source: Statistical office of the Republic of Serbia (2005-2016). Statistical Yearbook.

According to the data of the Statistical Office of the RS, employment in Serbia in 2015 amounted to 2.574 .200 , being higher for $0.6 \%$ compared to the previous year. However, registered employment in 2016 amounted to 2.009.784 (Statistical office of the Republic of Serbia, 2017).

Conducted analysis indicates that structural changes in the Serbian economy have contributed to the reduction of agricultural and manufacturing relative importance and increased relative importance of the service sector, measured by their participation in gross domestic product and overall employment.

Salaries of employees in Serbia at the economy and sector level recorded slight fluctuations in their nominal and real values in the previous period. In 2015, the average earnings of employees in Serbia registered a nominal decline of $0.5 \%$ and a real fall of $2.4 \%$. However, "the highest increase in wages was recorded in the following sectors: other service activities (nominal growth of $10.1 \%$ and real $8.0 \%$ ), arts, entertainment and recreation (nominal growth of $8.4 \%$ and real growth of $6.4 \%$ ) and health and social protection (nominal growth of $6.4 \%$ and real growth of $4.4 \%$ ). On the other hand, the largest negative changes were identified in the sectors: agriculture, forestry and fisheries (nominal decline of $10.2 \%$ and real growth of $11.9 \%$ ), mining (nominal decrease of $7.1 \%$ and real growth of $8.8 \%$ ) and manufacturing (nominal decline of $6.8 \%$ and real of $8.5 \%$ )" (Statistical Office of the RS, 2016, pp. 57-58).

\footnotetext{
* A new methodology for monitoring registered employment of Serbia is being applied since 2015, combining data from the two official statistical sources. The new definition of registered employment is in line with the standards of the European Union. Also, the methodology of the Labour Force Survey was changed in 2015. The system of grading, increased sample size, continuous research and new method of data collection - CAPI (Computer Assisted Personal Interviewing) have been changed. Accordingly, taking into account the changes in the methodology, the data from 2015 are not included in the analysis.
} 
The average gross and net salaries in Serbia in the period from 2003 to 2015 are given in Table 6 and Table 7.

Table 6 Average gross salaries in Serbia, per occupation, 2003-2015

\begin{tabular}{|c|c|c|c|c|c|c|c|c|c|c|c|c|c|}
\hline & 2003 & 2004 & 2005 & 2006 & 2007 & 2008 & 2009 & 2010 & 2011 & 2012 & 2013 & 2014 & 2015 \\
\hline Republic of Serbia, total & 16,612 & 20,555 & 25,140 & 31,745 & 38,744 & 45,674 & 44,147 & 47,450 & 52,733 & 57,430 & 60,708 & 61,426 & 61,145 \\
\hline $\begin{array}{l}\text { Agriculture, forestry and } \\
\text { water management }\end{array}$ & 13,129 & 15,569 & 20,301 & 25,951 & 29,680 & 37,204 & 38,421 & 38,304 & 43,857 & 49,948 & 51,916 & 51,522 & 52,435 \\
\hline $\begin{array}{l}\text { Agriculture, hunting and } \\
\text { services }\end{array}$ & 12,217 & 14,026 & 18,195 & 23,297 & 26,256 & 33,615 & 35,449 & 36,603 & 42,703 & 48,882 & 50,635 & 49,712 & 51,737 \\
\hline Forestry & 17,506 & 23,883 & 28,790 & 35,500 & 41,773 & 46,854 & 45,593 & 47,952 & 50,969 & 55,402 & 58,505 & 59,253 & 57,528 \\
\hline Water management & 20,479 & 26,050 & 34,020 & 42,238 & 48,655 & 55,946 & 53,683 & / & I & I & I & I & I \\
\hline Fishing & 15,378 & 17,840 & 24,085 & 23,724 & 21,699 & 29,113 & 27,147 & 32,818 & 34,506 & 44,102 & 44,107 & 48,289 & 38,819 \\
\hline Mining and quarrying & 22,091 & 26,352 & 30,745 & 38,992 & 48,978 & 55,835 & 61,226 & 69,582 & 80,605 & 89,521 & 96,051 & 97,900 & 99,521 \\
\hline Manufacturing & 12,996 & 16,065 & 20,366 & 25,830 & 30,620 & 36,540 & 35,166 & 40,101 & 45,269 & 49,236 & 51,742 & 53,094 & 56,471 \\
\hline $\begin{array}{l}\text { Production of electricity, } \\
\text { gas and water }\end{array}$ & 23,778 & 29,426 & 35,590 & 42,488 & 53,128 & 57,886 & 62,227 & 61,000 & 69,909 & 75,934 & 79,231 & 73,156 & 79,850 \\
\hline Construction & 15,175 & 18,443 & 22,389 & 28,219 & 34,944 & 42,271 & 37,897 & 40,985 & 45,796 & 48,159 & 49,492 & 51,778 & 57,023 \\
\hline $\begin{array}{l}\text { Wholesale and retail } \\
\text { trade, repair }\end{array}$ & 13,704 & 17,444 & 22,621 & 28,926 & 34,685 & 42,367 & 32,746 & 35,560 & 39,010 & 42,598 & 45,677 & 45,801 & 46,969 \\
\hline Hotels and restaurants & 11,689 & 14,037 & 17,665 & 21,516 & 25,844 & 30,234 & 24,895 & 25,851 & 28,588 & 31,303 & 33,044 & 33,620 & 36,449 \\
\hline $\begin{array}{l}\text { Traffic, storage and } \\
\text { connection }\end{array}$ & 20,113 & 24,561 & 29,737 & 36,029 & 41,568 & 48,758 & 51,350 & 58,090 & 65,185 & 72,086 & 77,563 & 83,897 & 86,839 \\
\hline Financial intermediation & 34,601 & 43,870 & 56,348 & 70,864 & 82,041 & 91,023 & 94,568 & 96,920 & 99,978 & 105,414 & $\begin{array}{r}109,47 \\
0\end{array}$ & 105,479 & 107,340 \\
\hline Real estate, renting & 20,251 & 24,730 & 32,076 & 37,039 & 47,154 & 52,116 & 46,840 & 51,326 & 56,246 & 61,378 & 65,571 & 66,981 & 68,079 \\
\hline $\begin{array}{l}\text { Public administration } \\
\text { and social security }\end{array}$ & 22,742 & 27,207 & 33,210 & 40,542 & 47,728 & 54,273 & 55,363 & 58,330 & 65,427 & 71,200 & 75,098 & 74,738 & 67,151 \\
\hline Education & 18,243 & 21,688 & 27,265 & 33,166 & 40,286 & 48,299 & 49,958 & 50,141 & 53,273 & 56,906 & 59,573 & 59,961 & 55,860 \\
\hline Health and social work & 18,817 & 23,064 & 26,792 & 32,790 & 42,900 & 48,864 & 50,444 & 50,503 & 54,691 & 57,803 & 60,569 & 60,359 & 56,307 \\
\hline $\begin{array}{l}\text { Other communal and } \\
\text { social services }\end{array}$ & 19,707 & 24,191 & 28,846 & 33,866 & 38,641 & 44,281 & 42,267 & 41,807 & 42,846 & 47,258 & 50,637 & 43,371 & 45,899 \\
\hline
\end{tabular}

Source: Statistical office of the Republic of Serbia (2005-2016). Statistical Yearbook.

Based on Table 6, gross salaries in agriculture in 2003 amounted only to $76 \%$ of the average gross salaries in Serbia. With mild oscillations in other analyzed years, in 2014 they make up $85 \%$ of average gross salaries in Serbia. Within the primary sector, the lowest gross salaries are recorded in the activities of agriculture, hunting and services, which are at the same time the lowest or one of the lowest gross salaries in comparison to all other activities in Serbia. The largest gross salaries in the whole observed period were recorded within the financial intermediation, which are almost twice than average for Serbia. Observed by sectors, both secondary and tertiary sectors on average achieve higher gross salaries than the national average. However, at the beginning of the analyzed period (2003), the tertiary sector recorded gross salaries for $20 \%$ higher than the national average, and the secondary $11 \%$. At the end of the analyzed period, in 2015 , a larger difference compared to the national average is recorded in the secondary sector $(20 \%)$, and smaller in the tertiary (4\%). 
Table 7 Average gross salaries in Serbia, per occupation, 2003-2015

\begin{tabular}{|c|c|c|c|c|c|c|c|c|c|c|c|c|c|}
\hline & 2003 & 2004 & 2005 & 2006 & 2007 & 2008 & 2009 & 2010 & 2011 & 2012 & 2013 & 2014 & 2015 \\
\hline Republic of Serbia, total & 11,500 & 14,108 & 17,443 & 21,707 & 27,759 & 32,746 & 31,733 & 34,142 & 37,976 & 41,377 & 43,932 & 44,530 & 44,432 \\
\hline $\begin{array}{l}\text { Agriculture, forestry and } \\
\text { water management }\end{array}$ & 9,076 & 10,658 & 13,835 & 17,683 & 21,244 & 26,696 & 27,582 & 27,591 & 31,545 & 35,970 & 37,404 & 37,212 & 37,908 \\
\hline $\begin{array}{l}\text { Agriculture, hunting and } \\
\text { services }\end{array}$ & 8,437 & 9,592 & 12,396 & 15,875 & 18,823 & 24,179 & 25,497 & 26,380 & 30,733 & 35,238 & 36,491 & 35,934 & 37,398 \\
\hline Forestry & 12,162 & 16,400 & 19,619 & 24,189 & 29,823 & 33,488 & 32,627 & 34,000 & 36,558 & 39,734 & 42,073 & 42,653 & 41,596 \\
\hline Water management & 14,177 & 17,907 & 23,243 & 28,778 & 34,616 & 39,809 & 38,275 & I & I & I & t & I & 1 \\
\hline Fishing & 10,659 & 12,214 & 16,341 & 16,137 & 15,592 & 20,921 & 19,569 & 23,692 & 24,944 & 31,838 & 31,990 & 35,016 & 28,145 \\
\hline Mining and quarrying & 15,373 & 18,113 & 20,989 & 26,739 & 34,818 & 39,729 & 43,650 & 49,630 & 57,436 & 63,726 & 68,338 & 69,660 & 71,077 \\
\hline Manufacturing & 8,990 & 11,034 & 13,945 & 17,710 & 22,066 & 26,391 & 25,539 & 29,057 & 32,785 & 35,748 & 37,706 & 38,735 & 41,148 \\
\hline $\begin{array}{l}\text { Production of electricity, } \\
\text { gas and water }\end{array}$ & 16,486 & 20,186 & 24,369 & 28,994 & 37,867 & 41,222 & 44,239 & 43,500 & 49,893 & 54,176 & 64,554 & 57,873 & 57,133 \\
\hline Construction & 10,472 & 12,597 & 15,235 & 19,195 & 24,869 & 30,178 & 27,175 & 29,459 & 32,950 & 34,713 & 35,747 & 37,493 & 41,744 \\
\hline $\begin{array}{l}\text { Wholesale and retail } \\
\text { trade, repair }\end{array}$ & 9,474 & 11,953 & 15,498 & 19,863 & 24,934 & 30,561 & 23,757 & 25,830 & 28,475 & 31,078 & 33,614 & 33,827 & 34,606 \\
\hline Hotels and restaurants & 7,991 & 9,498 & 12,000 & 14,678 & 18,614 & 21,800 & 18,176 & 18,899 & 20,902 & 22,832 & 24,362 & 24,885 & 26,781 \\
\hline $\begin{array}{l}\text { Traffic, storage and } \\
\text { connection }\end{array}$ & 13,911 & 16,854 & 20,341 & 24,724 & 29,821 & 35,046 & 36,880 & 41,676 & 46,878 & 51,696 & 56,674 & 62,250 & 64,714 \\
\hline Financial intermediation & 24,157 & 30,347 & 38,852 & 48,896 & 58,951 & 65,419 & 67,899 & 70,045 & 71,938 & 76,195 & 79,168 & 76,432 & 77,840 \\
\hline Real estate, renting & 14,052 & 17,028 & 22,007 & 25,387 & 33,888 & 37,531 & 33,851 & 37,041 & 40,581 & 44,395 & 47,675 & 48,768 & 50,796 \\
\hline $\begin{array}{l}\text { Public administration } \\
\text { and social security }\end{array}$ & 15,767 & 18,673 & 22,633 & 27,630 & 34,055 & 38,730 & 39,494 & 41,675 & 46,728 & 50,824 & 53,826 & 53,413 & 48,161 \\
\hline Education & 12,574 & 14,826 & 18,550 & 22,583 & 28,781 & 34,451 & 35,666 & 35,867 & 38,152 & 40,764 & 42,757 & 43,031 & 40,217 \\
\hline Health and social work & 13,063 & 15,868 & 18,328 & 22,334 & 30,654 & 34,878 & 36,030 & 36,149 & 39,220 & 41,456 & 43,620 & 43,445 & 40,649 \\
\hline $\begin{array}{l}\text { Other communal and } \\
\text { social services }\end{array}$ & 13,635 & 16,616 & 19,693 & 23,099 & 27,648 & 31,674 & 30,335 & 30,127 & 31,749 & 34,184 & 44,173 & 36,990 & 35,866 \\
\hline
\end{tabular}

Source: Statistical office of the Republic of Serbia (2005-2016). Statistical Yearbook.

On the other hand, Table 7 shows net earnings in all activities in Serbia. The ratio of net salaries is the same as for gross salaries. Therefore, in agriculture only around $80 \%$ of average net salaries in Serbia are realized. They also represent the lowest earnings in relation to other activities. Both the secondary and tertiary sector as a whole realize their net earnings at the sector level above the national average. As with gross salaries, at the beginning of the analyzed period, the tertiary sector as a whole has higher average salaries compared to the secondary (20\% compared to $11 \%)$, while this ratio changes at the end of the analyzed period in favor of the secondary (18\% compared to $4 \%$ ). 


\subsection{The share of economic sectors in international trade of the Republic of Serbia}

Commercial liberalization, both at regional and global level, has created a global environment suitable for the growth and expansion of world trade. New technologies, such as computers, telecommunications and other media, have contributed to the integration of the world market.

As the most traditional form of international business activity, international trade involves the exchange of goods and services across national borders. It allows businesses and distributors to search for goods, services, or parts of products in other countries.

Foreign trade is an important indicator of economic development of the country and it brings many benefits to both exporting and importing countries. While exporting countries earn by exporting surplus of their products, importing countries have access to better products and thus affect the living standard of the population. The main determinants of exports are the presence of entrepreneurial spirit, access to marketing, transport and other services, exchange rate, but also the state trade policy and policies of the exchange rate. On the other hand, imports are mostly influenced by income per capita, prices of imports, exchange rate, public policies related to trade and exchange rate and availability of foreign currencies (Seyoum, 2009, pp. 9-10).

There are numerous reasons in favor of international trade, such as cost efficiency, the use of advanced technology, new production methods, specialization, improvement of living standards, etc. International trade also allows businesses to access resources that are not available in their countries. However, in addition to providing consumers with a wide range of different products, international trade increases revenue and employment. By encouraging the development of agriculture, manufacturing and service sectors, foreign trade offers greater employment opportunities in these sectors. Also, foreign trade stimulates market competition and thus leads to the improvement of production technology, production process and product quality. The ultimate benefit is realized by consumers who receive quality and varied products at affordable prices.

Tables 8 and 9 show the values of Serbian exports and imports in millions of dinars for the period from 2003 to 2015. Therefore, based on the values from the tables, the absolute value of Serbian exports and imports in the observed period is growing both in total and by sectors. In the first half of the analyzed period (from 2003 to 2009), the value of imports is about twice higher than the value of exports, while in the second half of the analyzed period (from 2010 to 2015) the value of exports and imports is approximating. Within the primary sector, agriculture, hunting and services account for almost $95 \%$ of foreign trade, while the rest is farming, forestry and fisheries.

In Table 10 relative values of exports and imports in the primary, secondary and tertiary sectors of Serbia are given. 

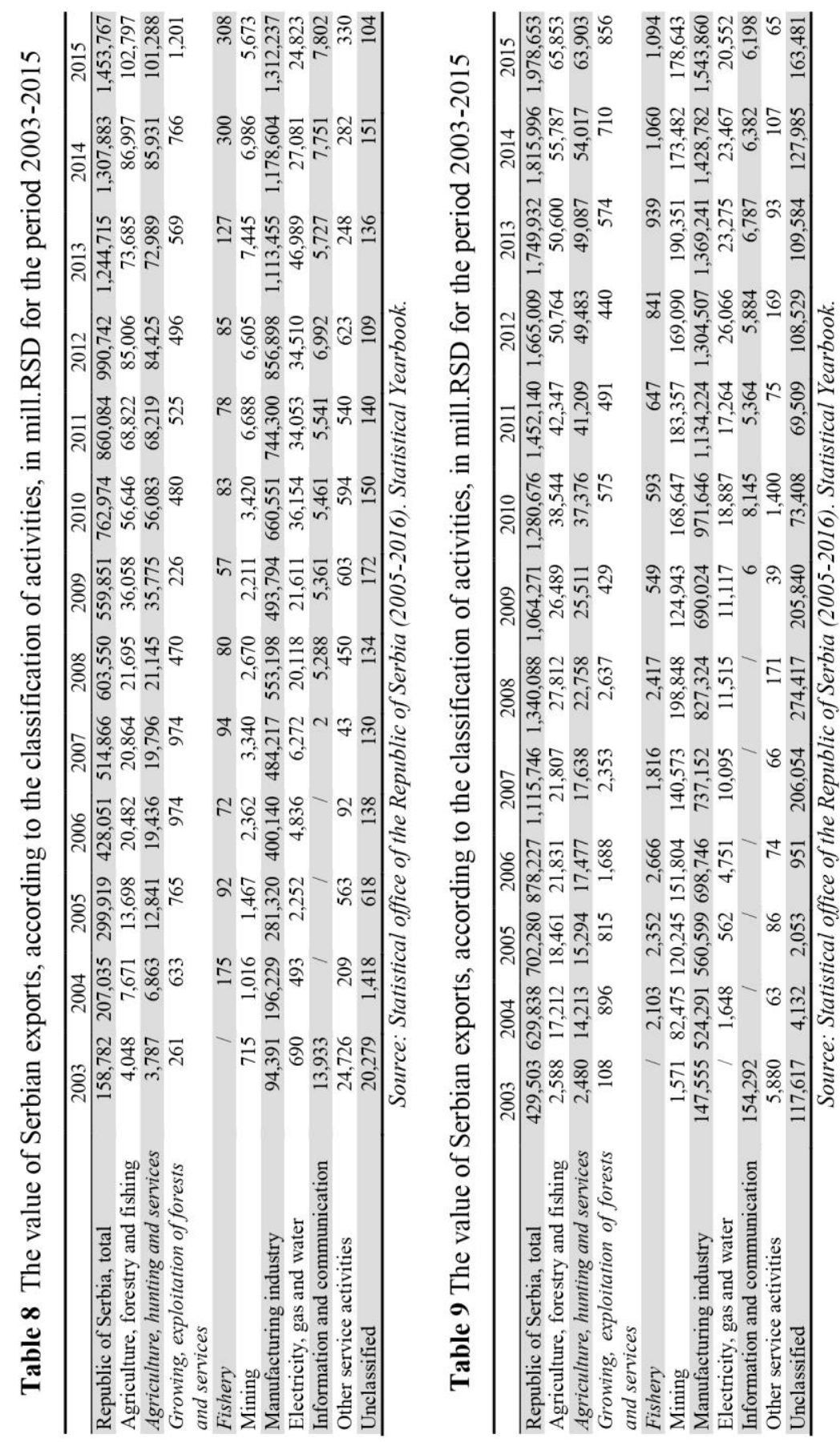
Table 10 Share of agriculture, manufacturing and services in Serbian exports and imports, for the period 2003-2015

\begin{tabular}{rrrrrrrrr}
\hline \multirow{2}{*}{ Year } & \multicolumn{2}{c}{ Agriculture } & \multicolumn{2}{c}{ Manufacturing } & \multicolumn{2}{c}{ Service sector } & \multicolumn{2}{c}{ Nonaligned } \\
\cline { 2 - 8 } & Export & Import & Export & Import & Export & Import & Export & Import \\
\hline 2003 & $2.55 \%$ & $0.60 \%$ & $60.33 \%$ & $34.72 \%$ & $24.35 \%$ & $37.29 \%$ & $12.77 \%$ & $27.38 \%$ \\
2004 & $3.71 \%$ & $2.73 \%$ & $95.51 \%$ & $96.60 \%$ & $0.10 \%$ & $0.01 \%$ & $0.68 \%$ & $0.66 \%$ \\
2005 & $4.57 \%$ & $2.63 \%$ & $95.04 \%$ & $97.03 \%$ & $0.19 \%$ & $0.01 \%$ & $0.21 \%$ & $0.29 \%$ \\
2006 & $4.78 \%$ & $2.49 \%$ & $95.16 \%$ & $97.39 \%$ & $0.02 \%$ & $0.01 \%$ & $0.03 \%$ & $0.11 \%$ \\
2007 & $4.05 \%$ & $1.95 \%$ & $95.91 \%$ & $79.57 \%$ & $0.01 \%$ & $0.01 \%$ & $0.03 \%$ & $18.47 \%$ \\
2008 & $3.59 \%$ & $2.08 \%$ & $96.43 \%$ & $44.43 \%$ & $0.95 \%$ & $0.01 \%$ & $0.02 \%$ & $20.48 \%$ \\
2009 & $6.44 \%$ & $2.49 \%$ & $92.46 \%$ & $77.62 \%$ & $0.07 \%$ & $0.55 \%$ & $0.03 \%$ & $19.34 \%$ \\
2010 & $7.42 \%$ & $3.01 \%$ & $91.76 \%$ & $90.51 \%$ & $0.79 \%$ & $0.75 \%$ & $0.02 \%$ & $5.73 \%$ \\
2011 & $8.00 \%$ & $2.92 \%$ & $91.27 \%$ & $91.92 \%$ & $0.71 \%$ & $0.37 \%$ & $0.02 \%$ & $4.79 \%$ \\
2012 & $8.58 \%$ & $3.05 \%$ & $90.64 \%$ & $90.07 \%$ & $0.77 \%$ & $0.36 \%$ & $0.01 \%$ & $6.52 \%$ \\
2013 & $5.92 \%$ & $2.89 \%$ & $93.83 \%$ & $90.45 \%$ & $0.48 \%$ & $0.39 \%$ & $0.01 \%$ & $6.26 \%$ \\
2014 & $6.65 \%$ & $3.07 \%$ & $92.72 \%$ & $89.52 \%$ & $0.61 \%$ & $0.36 \%$ & $0.01 \%$ & $7.05 \%$ \\
2015 & $7.07 \%$ & $3.33 \%$ & $92.36 \%$ & $88.09 \%$ & $0.56 \%$ & $0.32 \%$ & $0.01 \%$ & $8.26 \%$ \\
\hline
\end{tabular}

Source: Statistical office of the Republic of Serbia (2005-2016). Statistical Yearbook.

The share of agriculture in the total export of Serbia increased from $2.55 \%$ in 2003 to $7.07 \%$ in 2015 (Table 10). Also, agriculture has slightly increased its share in total imports (3.33\% in 2015 compared to $0.60 \%$ in 2003). Manufacturing is constantly registering a significant share in exports (on average 90\%) and in imports (on average $85 \%$ ) of Serbia. The service sector, on the other hand, has an extremely low share in total exports and imports throughout the analyzed period. With a relative share in exports and imports of around 1\%, the tertiary sector has the least share in Serbian exports and imports compared to primary and secondary sectors.

\section{CONCLUSION}

Structural changes can be considered as a result of a process in which economies, both national and global, but also sectors and regions, show their ability to survive in conditions of fierce competition and respond to new market challenges. Structural changes, above all, represent a change in the relative importance of the economic sectors over a certain period of time, measured by their participation in the national product and overall employment. There is a whole set of factors that lead to a change at different levels. Bearing this in mind, there is no single and unique factor that causes structural changes, but they are most often the result of a combination of determinants.

In the long term, structural changes show a strong correlation with changes in the competitiveness of the economy and therefore its development, as well as changes in economic results at the micro and macro level. There is a constant process of economic restructuring as a result of technological and social changes, combined with competitive and comparative advantages, constantly changing the sectoral and spatial dynamics of economic activity in the global economy. The rapid economic development, in general, is driven by structural changes in the economy, as well as structural changes in its 
various sectors. These fundamental changes are characterized by shifting resources from primary production, such as agriculture and mining, to manufacturing, and within manufacturing from those based on natural resources to those more sophisticated, more intense in terms of skills and technology, and further towards the tertiary sector.

Intersectoral structural changes in Serbia were examined in the paper on this base. As of the sector's share in the gross domestic product, the tertiary sector accounts for about $60 \%$ of GDP in the analyzed period, followed by a secondary sector with around $30 \%$ and a primary sector that records the share of around $10 \%$. When it comes to the share of sectors in the overall employment in Serbia, the conducted analysis shows that the dominant share in the total employment has a tertiary sector with over $60 \%$, followed by a secondary sector with over $30 \%$ and a primary sector that participates with less than $5 \%$ in overall employment. Therefore, it can be concluded based on the results that the tertiary sector has the biggest contribution to the economic growth of Serbia, then secondary sector and the least contribution has the primary sector. However, the share of sectors in the exports and import values indicates slightly different results. Namely, almost all exports and imports in Serbia relate to the secondary sector which participates with about $90 \%$. The primary sector accounts for less than $10 \%$ in exports and imports, and the tertiary sector records a negligible share in exports and imports of around $1 \%$.

Acknowledgement: The paper is a part of the research done within the project 179066, funded by the Ministry of Education, Science and Technological Development of the Republic of Serbia.

\section{REFERENCES}

Adelman, I. (1999). Fallacies in Development Theory and Their Implications for Policy. In M. \&. Stiglitz, Frontiers of development economics: The future in perspective (pp. 103-134). New York: World Bank.

Ark, V. (1995). Sectoral Growth Accounting and Structural Change in Postwar Europe. Groningen Growth and Development Centre, University of Groningen.

Dietrich, A. (2009). Does Growth Cause Structural Change, or Is it the Other Way Round? A Dynamic Panel Data Analyses for Seven OECD Countries. Jena: Jena Economic Research Papers.

Downes, P. \& Stoeckel, A. (2006). Drivers of Structural Change in the Australian Economy. Sydney: Centre for International Economics - Canberra \& Sydney.

Frane, A. (2014). Measuring National Innovation Performance. Springer Briefs in Economics.

Hayami, Y. \& Godo, Y. (2005). Development Economics: From the Poverty to the Wealth of Nations. Oxford: Oxford University Press.

Johnston, W. (1990). Structural Change and the Recognition of Diversity. American Journal of Agricultural Economics, 72, 1109-1123.

Kenneth, D., Caroline, J. \& Lynk, E.L. (1992). Industrial Organization: Competition, Growth and Structural Change. London: Routledge.

Крстић, Б., Станојевић, Ј., Станишић, Т. (2015). Глобализација и њене импликације као једног од најзначајнијих фактора структурних промена [Globalization and its implications as one of the most important drivers of structural changes]. Друштвени и технолошки развој у ери глобализације - СЕРДА 2015 (стр. 31-44). Бијељина: Слобомир П Универзитет.

Memedovic, O. \& Lapadre, L. (2010). Structural Change in the World Economy: Main Features and Trends. Vienna: United Nations Industrial Development.

Mankiw, G. (2002). Principles of Economics. South-Western Cengage Learning.

Mankiw, G. (2001). Principles of Macroeconomics. South-Western Cengage Learning.

Raiser, M. Schaffer, M. \& Schuchhardt, J. (2003). Benchmarking structural change in transition. European Bank for Reconstruction and Development.

Quatraro, F. (2012). The Economics of Structural Change in Knowledge. Valbonne: Routledge. 
Seyoum, B. (2009). Export-Import Theory, Practices, and Procedures. London: Routledge.

Statistical Office of the Republic of Serbia. (2018). Retrieved: www.stat.gov.rs.

Statistical Office of the Republic of Serbia. (2005-2016). The Statistical Yearbook

WEF. (2016-2017). Global Competitiveness Report. Geneva: World Economic Forum.

\section{MEĐUSEKTORSKE VEZE I NJIHOV DOPRINOS EKONOMSKOM RASTU U REPUBLICI SRBIJI}

Visok nivo međusobne povezanosti privrednih sektora, odnosno agrarnog, industrijskog $i$ sektora usluga, ukazuje na potrebu razumevanja međusektorskih strukturnih promena i transfera resursa između sektora, a u cilju sagledavanja njihovog doprinosa ekonomskom razvoju. Međusektorske strukturne promene Republike Srbije, kao jedne od tranzicionih privreda, analiziraju se sa različitih aspekata na osnovu bogate informacione osnove koju čine podaci iz domaćih i međunarodnih statističkih izvora. U radu se, pre svega, sagledava učešće privrednih sektora u bruto domaćem proizvodu. Zatim se ukazuje na udeo privrednih sektora u ukupnoj zaposlenosti, ali $i$ u međunarodnoj trgovini. Cilj istraživanja jeste da se analiziraju strukturne promene u privredi Republike Srbije, identifikuje pravac transfera resursa između sektora, kao $i$ utvrdi njihov doprinos ekonomskom razvoju mereno različitim indikatorima.

Ključne reči: međusektorske veze, strukturne promene, ekonomski rast, Republika Srbija. 